\title{
Always in the Limelight: Critical Responses to English Geetagalu
}

Shivarama Padikkal

\begin{abstract}
This paper shall attempt to capture a few moments in the history of the reception of 'English Geetagalu' by the Kannada reading public by way of reading some of the critical responses to it so as to sketch the 'primary role' it has supposedly played in fashioning modern Kannada literature. It argues that the text 'English Geetagalu' bears the marks of the discourse of colonial modernity that produced it as a canonical one. Also, in the context of 'English Geetagalu' it attempts to revisit the question of 'invisibility' or the 'marginality' of translators-a question that has been raised time and again in Translation Studies. It would argue along with Tejaswini Niranjana that the translator's preoccupation with the method and eagerness to present the translated text as a unified and transparent whole results in the exclusion of the translator from the text to which the translator gives an after-life. Despite their exposure, training and explicit belief in the humanist tradition of the West, the early Kannada translators such as B.M. Srikantia (1884-1946) seem to overcome this predicament in their practice.
\end{abstract}

Any analysis of the reviews of translated texts must situate the translated texts and reviews in the larger context of literary production and consumption at a particular point in time in history. We need to discuss the different kinds of reading public and their perception of literariness, their literary sensibility, institutionalization of literature and so on. Such a study also involves an analysis of the

Translation Today Vol. 5 No. 1 \& 22008 ㄷ CIIL 2008 
production and consumption of translated texts in a particular literary culture. Secondly, any literature is a production of culture and in that very process of production it re-produces culture or modifies it according to the social aspirations of the social group that creates such texts. Review, reception, critical engagement etc., therefore represent the nature of the emerging culture at a point in time in history.

As most of us are aware, systemic theorist Itamar Even Zohar, while discussing the position of a translated text in the literary poly system, has noted that translated texts either play a primary or a secondary role in the literary poly system of the receptor language. When they play a primary role, translated texts change all the literary relations in that language and breathe in a fresh air and rewrite the history of literature. They even inaugurate a new literary movement in a given literature. Indian languages have witnessed this role of translated texts in the late nineteenth century and in the early twentieth century. Translators were most visible during this period. For example, as I have noted elsewhere, B. Venkatacharya has translated almost all the novels of Bankimchandra directly from Bengali. He went to Calcutta, learnt Bangla in order to translate these texts. His translations were regarded as 'Venkatacharya's novels' in Kannada and very popular in the first decades of the twentieth century. Readers also consider him 'Kannada kaadambariya Janaka' (Father of the Kannada Novel), for his translations attracted the reader to the fascinating world of the novel and many new writers tried their hand at that genre later.

English Geetagalu, a collection of translations of some English poems from Golden Treasury by B.M. Srikantia, the first joint professor of Kannada and English in Mysore University, is another text that has always been in the limelight. It practically provided a model for new poems among Kannada readers who were looking forward to have such a model. Many critics think that English Geetagalu marks the beginning of the 'Navodaya' literary movement in Kannada.

B.M.Sri, as he was popularly known, has mostly translated the texts of English Romantic poets in this collection. It first appeared in book form in 1926. And within ten years it acquired a canonical 
status. And B.M.Sri is the only writer in Kannada to receive the first felicitation volume in 1941. His birth centenary year 1984 witnessed five centenary commemoration volumes in Kannada. He was the President of Kannada Sahitya Parishat and a Kannada activist. But as far as his literary contributions are concerned, apart from English Geetagalu he has published only one collection of poems Honganasugalu and one play and translated Greek tragedies into Kannada.

Why did B.M.Sri choose to translate the English Poems? In his preface to English Geetagalu he says that he wanted to bring the universal themes of poetry such as war, love, death, patriotism, nature, love for god, beauty etc., into the realm of Kannada poetry. He felt that traditional poetry was not suitable to fulfil the aspirations of the modern self. We need to write differently in a language and a different theme, argued B.M.Sri. ${ }^{2}$

B.M.Sri was conscious of his translation project. He was a builder of Modern Kannada Language. He intended to regenerate Kannada language through modern poetry. He decided to translate so as to provide a suitable model before the young Kannada writers. So he says:

I don't think that all the poems translated in this collection are the best of English poetry. Not all of them represented over here are the best English poets. I have selected those poems, which I thought I could manage to translate. I liked and enjoyed most of them. Also I wish to show how the English poets treat the theme of love with seriousness and sensitivity. In this collection such love poems are more in number.

I hope that from these shells thrown on the Kannada beach by the great waves of English Poetry our readers will experience the beauty, radiance, fragrance, and taste of that great ocean. (Srikantia 1985: v) 
The strategy followed by B.M.Sri in translating these poems is also interesting. B. M. Sri believed in a certain kind of Universal Humanism and therefore he thought that the themes he has chosen could be rewritten in the Kannada language so far as they represent the same universal experience in Kannada. So he did a creative rendering of the English poems. But During those days poetry had to be metrical and had to follow the second syllable alliteration in Kannada. Before B. M. Sri, Hattiyangadi Narayana Rao had translated some English poems into Kannada as Angla Kavitavali. He maintained all the metrical rules of old Kannada poetry. B. M. Sri did not follow this tradition, but instead violated it. He researched into several Dravidian meters available in folk songs and rearranged them while translating the English poems. Interestingly, he did not use the term poetry like Narayana Rao but used the term 'Geetagalu' or Songs. Kannada has a rich tradition of Folk and Dasa songs and B. M. Sri chose to follow them rather than write in the epic tradition of Kannada. Consequently, the new poetry in Kannada appeared in the form of songs with a certain rhyme and rhythm. They became immensely popular.

P. B. Shelley's 'To' begins with the lines

'I fear thy kisses, gentle maiden

Thou needest not fear mine' (qtd. in Srikantia 1985: 103)

'hedaruvenu na ninna binnaNakele heNNe

Hedaradiru niinu nanage' (Srikantia 1985: 102)

Or Walter Scott's 'The Pride of Youth'

'Proud Maisie is in the wood

Walking so early' (qtd. in Srikantia 1985:92)

'Cimmuta niriyanu banadali bandaLu

binkada singari’ (Srikantia 1985: 93) 
Domestication is another strategy followed by B. M. Sri. In the above lines too women characters that appear in the Kannada translation are the new Kannada women, not the English ones. In the same way, 'Auld Robin Gray' becomes 'Old Rame Gowda' in his translations, Lord Ullin's Daughter, 'Kaari Heggade Magalu'. B. M. Sri not only changes the names, locations and rhythms of English Poetry but also modifies the traditional structures of Kannada songs in order to create a completely new range of communicative network.

B. M. Sri's translations are actually a practical demonstration of his larger agenda for the regeneration of Kannada language. In his famous speech to Kannada Vidyavardhak Sangha in 1911 he has put forward his views on the regeneration of Kannada. He clearly argues that Kannada should stop imitating Sanskrit blindly. Sanskrit could be the base but one cannot move forward if he/she doesn't come out of the clutches of tradition. English is the path that can lead us to a new future. We need to create a cultural ideal blending the best ideals of Kannada and English. Further he says:

Use new Kannada for all writings. Old Kannada should be used only for the texts that have to be understood by the educated class or for great epics. We should not mix these two. The standard Kannada should not be infiltrated by rustic words. It has to be the language of the educated and upper caste people. By teaching this language in schools, we can make it popular.

(Srikantia 1985: 254)

Though B. M. Sri worked on Kannada songs, in actuality, he standardized them in his translations. His attempt was to create a standard Kannada that can be spoken and written by women, men, children, elders, Brahmins, and Vokkaligas, who are the new reading public. B. M. Sri's project of cultural regeneration is very clearly related to the idea of the construction of a normative Kannada sensibility and Kannadaness. This normative Kannada subject is the English-educated, rooted in tradition but an open-minded humanist. 
He also represents a refined literary sensibility. In fact B.M. Sri's own generation of English-educated Kannadigas represent the kind of secular self he was trying to give voice to through his translations. Hence, English Geetagalu acquired fame immediately after its publication.

There are umpteen number of writings on English Geetagalu. I have chosen to present before you two or three representative commentaries and readings done at different points of time.

The first set of critical responses is completely appreciative of B. M. Sri's effort. For example, M. V. Seetaramaiah, in his introduction to English Geetagalu calls it a gem of a translation. For him selecting the poems from English romantic poetry is a significant decision. This choice of Romantic poets such as Wordsworth, Coleridge, Shelley etc., deviated from the classical tradition in order to take poetry closer to the people. In Kannada too there was a need to come out of the 'Pandita Sampradaya' (scholarly tradition) to rejuvenate Kannada literature. English Geetagalu is a significant step in that direction. Relieving Kannada poetry from the clutches of the compulsory Sanskrit metrical arrangements of 'praasa', 'anuprasa', 'kanda', 'shatpadi' and experimenting with indigenous prosody was yet another goal of English Geetagalu. ${ }^{3}$

Most of the writers who were later considered as makers of Kannada literature such as Shivarama Karanth, D. R. Bendre, Masti Venkatesha Iyengar, V. Seetaramaiah, K. S. Narasimha Swamy follow this line of argument that English Geetagalu not only brought new themes to the realm of Kannada but also served as a model for modern Kannada poetry.

However 'traditionalists' criticized English Geetagalu for corrupting the Kannada/Indian tradition. In what we today consider as the 'old Mysore' area, comprising the districts around Mysore and Bangalore, it is said that writers belonged to two main camps. One is the Hirannayya tradition. Hirannayya is a philosopher who translated 
the Sanskrit Alankara Shastra into English. He was of the opinion that we have to develop an aesthetic tradition based on Alankara Shastra. The other tradition was B. M. Sri's that strongly stood for transformation of Kannada literature along the lines of English. They were criticized for their love towards English in the other circles. The traditionalists did not like B. M. Sri's efforts. However, modern Kannada poetry moved forward on B. M. Sri's model.

The third set of readings represents the progressive writers. Though they acknowledged the historical significance of B. M. Sri's translations, they criticized the romantic themes projected by B. M. Sri. They strongly argued against the 'people with close collar coats and gold threaded shawls, against 'rajasevasaktas'. Their contention was that B.M. Sri did not respond to the realities of princely Mysore. While people were suffering from poverty, English Geetagalu provides romantic poetry to them. B. M. Sri had immense respect for Mysore Maharaja and the Colonial government. They cite the example of the translation of 'Rule, Britannica' and several such English patriotic songs in justifying their argument. A modernist critic G. H. Nayak also criticizes the elitist and Brahmincal agenda in English Geetagalu. He argues that B M Sri was very clearly accepted as the role model of English education and supremacy of English literature. English Geetagalu is dedicated "To my students in the University of Mysore who believe in the blending of the soul of India and England" (Nayak 1988: 140).

The fourth set of comments is by the new critics or those who belong to the Navya movement in Kannada. For example, critic M. G. Krishna Murthy (MGK) criticizes B. M. Sri for his lack of critical judgment in the selection of poems from English Romantic poetry. He argues that B. M. Sri is not a critical reader of English poetry and was completely influenced by the contemporary fads. MGK's criticism is that it was unfortunate that B. M. Sri did not choose to translate English metaphysical poetry. He suggests that if B. M. Sri had translated English metaphysical poems, modern Kannada poetry would have been fashioned in a very different way (Krishnamuthy 1970: 60). It is true 
that Kannada has a rich tradition of reflective poetry such as 'vacanas' of $12^{\text {th }}$ century, 'lavanis' of $18-19^{\text {th }}$ century, 'dasa' songs of $15^{\text {th }}$ century, the 'sufi' tradition and so on. However, he does not give us any reasons why others did not bring in those traditions to modern Kannada. MGK is very unhappy about the choice of Romantic poems, for they are too simplistic.

The last set of readings is by very recent scholars such as V. B. Tharakeshwar. Tharakeshwar attempts to read the role of English in constituting the Kannada language and literary culture against the backdrop of the caste politics of princely Mysore under colonial rule. He concludes:

If in the context of English Geetagalu we look at how Kannada Nationalism and Indian Nationalism responded to the backward communities it is clear that the English educated elite were in the forefront of the nationalist movement and how in princely Mysore they were controlling the means of intellectual production. They successfully tried to co-opt others into the movement by negotiating with these communities through the discourse of Kannada against the colonial discourse and using the same discourse is the strategy adopted by B. M. Sri in his English Geetagalu. In other words, during colonialism the local elite trained in terms of master discourse experiences an anxiety about his own identity. In order to regenerate his/her culture the elite turns to the master narrative and changes the terms of that narrative in such a way that it sounds local. There exists already a readership for such literary texts. (Tharakeshwar 2002: 237)

This is a possible explanation for the success of English Geetagalu and its canonization. In my opinion English Geetagalu writes modernity into Kannada language and culture. B. M. Sri also translated Greek tragedies into Kannada. Here also he takes the form and then fills the Kannada content into the form. Thus Ajax becomes Ashwattaman in Kannada. 
One of the significant things that we observe among early Kannada translators is that they felt free to interpret the text. The question of fidelity did not bother them much. They also never said that they were translations to bridge the gap between two different cultures. Their main aim was to write new kinds of texts for the new generation and to bring in new ideas into Kannada.

They were trying to fashion a new language that could be used for the new political purposes. They also thought about texts that they were translating as their own texts. They never seem to have felt the marginality. These translations were also received and discussed as independent texts in Kannada. B. M. Sri wrote a prefatory poem in Geetagalu. It is titled 'Kanike' (offering). This poem is a demonstration of B. M. Sri's cultural project as well as his translation strategy:

'Kannada tongue; our girl,

The girl of our garden;

Later she grew up with others

Then came back to us,

Ripe new fruit

Came near us.

The golden girl of western sea,

The breath of my life, my eyes,

Taught me, made me happy and

Made me dance with her;

Once that girl, once this girl

Are making me dance

I felt joyful

I weighed both the loves

Tried to by dressing

The one with the other's beauty;

By putting the ornaments of one on the other

I tried to sing' ${ }^{4}$

This comfort with other texts and the confidence had disappeared with the advent of western notions of translation. Notions 
of fidelity, truthfulness etc., begin to dominate the scene in Kannada after the age of the early translators. Translation is also seen as a linguistic translation and transfer of the original meaning. In such a situation the translator is bound to become a mere artist or craftsman or a scientist as the dominant theories of translation inform us. When translators think that they are outside the text and are transferring the original meaning, their position is deemed to be marginal. As Tejaswini Niranjana (1992) has argued, it is the translators who exclude themselves from the text in order to present it as a unified and transparent whole. The commonsense that prevails in India about translation is constituted by such humanistic notion of translation. In my opinion, this is one of the major reasons why reviewers do not mention the translator.

\section{Notes}

1. 'Only English literature can rejuvenate our Kannada literature; only English can assuage the ills of our poetry that has been handed down to us from Sanskrit' argued B. M. Srikantia (1884-1946), popularly known as 'Kannada Kanva' and the 'Acharya Purusha' of modern Kannada literature. He published English Geetagalu, a collection of translations of English poems into Kannada in 1926 with the intention to re-energize Kannada as a modern literary language. English Geetagalu soon attracted a lot of critical attention and acquired the canonical status within ten years of its publication. Different communities of readers in the last ninety years have read and received it differently. English Geetagalu is seen as a text that has inaugurated the Navodaya literary movement in Kannada; provided new meters, rhymes and rhythms to modern Kannada poetry; represented the strength of Kannada in the process of translating; brought in the flavour of English poetry without losing the essential Kannada identity and so on. There were also, critical readings of English Geetagalu criticizing B. M. Srikantia's lack of critical acumen and his tendency to go along with the 'contemporary' fashions of English poetry while selecting the English poems for translation. But such a stance is an exception. The critics for various reasons consider English Geetagalu as a model text ever since it has been published. 
2. B. M. Sri's 'Preface' as quoted by V. Seetaramaiah in his 'Introduction' to the first edition of English Geetagalu published by B. M. Sri Smaraka Pratisthana, Bangalore in 1985.

3. Ibid vii.

4. B. M. Sri’s Poem 'Kanike’ as translated by V.B. Tharakeswar.

\section{References}

Krishnamurthy, M. G. (1970) Adhunika Bharatiya Sahitya Mattu Itara Lekhanagalu, Heggodu, Sagara: Akshara Prakashana.

Nayaka, G. H. (1988) Nijadani, Heggodu, Sagara: Akshara Prakashana.

Nayaka, H. M. (ed.) (1983) Sree Sahitya, Mysore: Prasaranga, Mysore University.

Niranjana, Tejaswini (1992) Siting Translation: History, PostStrucuralism, and the Colonial Context, Berkeley: University of California Press.

Panditaradhya, M. N.V. (ed.) (1985) Hattiyangadi Narayanarayara Angla Kavitavali, Mysore: Prabodha Pustaka Maale.

Srikantia, B.M. (1985) English Geetagalu, Bangalore: B.M. Sri Smaraka Pratisthana.

Tharakeswar, V.B. (2002) Colonialism, Nationalism and the "Question of English" in Early Modern Kannada Literature, Unpublished Ph. D Thesis: University of Hyderabad. 